\title{
THE WORLD ECONOMY AT THE END OF THE MILLENNIUM
}

\author{
by \\ DEEPAK LAL
}

\author{
Working Papers Number 786 \\ Department of Economics \\ University of California, Los Angeles \\ Bunche 2263 \\ Los Angeles, CA 90095-1477 \\ September 1998
}


Paper for the Rosecrance Festschrift

J.Mueller(ed) : Prosperity, Politics and Peace: Essays in honour of Richard Rosecrance, Westview Press, New York (in press)

THE WORLD ECONOMY AT THE END OF THE MILLENNIUM

by

Deepak Lal

James S. Coleman Professor of International Development Studies, University of California, Los Angeles

\begin{abstract}
The paper examines the rise fall and rise of the Liberal International Economic Order over the last 150 years, and critically examines the various hopes and fears in developed and developing countries that this most recent global integration is raising.
\end{abstract}

JEL classification: F02, A13, N70, P16.

Address: Dept. of Economics, UCLA, 405 Hilgard Ave., Los Angeles, CA 90024

Tel.: $310-825 \quad 4521$

Fax.: $310-825 \quad 9528$

e-mail: dlal@ucla.edu

FINAL REVISE September 1998 
THE WORLD ECONOMY AT THE END OF THE MILLENNIUM

by

Deepak Lal

INTRODUCTION

If a Rip van Winkle had gone to sleep at the end of about 1870 and woken up in the last few years, he would find that little has changed in the world economy. He would note the various technological advances in transportation and communications (airlines, telephones and the computer) which have further reduced the costs of international trade and commerce and led to the progressive integration of the world economy which was well under way after the first Great Age of Reform, when he went to sleep.

The terrible events of this century- two world wars, a Great Depression and the battles against two illiberal creedsFascism and Communism- which led to the breakdown of the first liberal international economic order(LIEO) - created under British leadership after the Repeal of the Corn Laws- would form no part of his memory. Nor would the various and varying fads in economic policy-both national and international - during this century make any sense, eg. exchange controls, the use of quotas rather than tariffs as instruments of protection, centralized planning and associated controls on production and distribution, and restrictions on the free flow of capital.

Having read his De Tocqueville he would also not be surprised that the US and Russia had become Great Powers in the latter part of this century. Nor, that it took the US nearly a century to become the predominant power, just as it took Britain 
nearly a century from the mid 18th century conflict with France till the end of the Napoleonic Wars to achieve its predominance. His reading of De Tocqueville would also allow him to see a natural progression from the rise of Great Britain -which was in a sense the victory of an aristocratic oligarchy over the divine right of kings- to that of the US, which is a victory of Demos over aristocracy. Whether this is an unmixed blessing is open to question. ${ }^{1}$

$\mathrm{He}^{2}$ would be surprised by two features of the current world economy. For unlike the 19th century when there was free movement of goods, money and people, today there are relatively free flows of goods and money but no free movement of labor. This is related to the second surprising feature he would observe: the welfare states to be found in most advanced countries, which as he would soon recognize, have created property rights in citizenship. This, necessarily leads to restrictions on immigration. For immigration creates new citizens with an automatic right of access to the purses of existing citizens through the transfer state.

Having gone to sleep in 1870 before the great scramble for Empire by the nations of Europe, and the universal spread of the Romantic movement's ideal of nationalism, he would also not be surprised by the twin theses of Dick Rosecrance who we are honoring at this conference. ${ }^{3}$ First, that the territorial imperative which had motivated competition between nation states since the end of the wars of religion was replaced by the commercial competition of trading states following the example of Great Britain in the first great Age of Reform. Second, that as more and more developing countries, particularly India and China with their vast pools of relatively cheap labor, are brought into an integrated world economy, a new international division of labor is emerging, with developed countries mainly providing services and developing ones manufactures. With this spatial division between 'the head' and 'the body' of economic activity, trade is becoming essential for the well-being of all countries, thus 
reducing the attractions of nationalism and war.

He would also not be surprised by the consensual economic policies increasingly embraced around the world as they echo those of the standard textbook of 19th century political economy - Mill's Principles. ${ }^{4}$ Though he would be surprised by the technicalities in which the discussions were conductedparticularly amongst the new breed of academic economists- he would have no difficulty in understanding and endorsing their prescriptions : sound money, Gladstonian finance and a general acceptance of the 19th century policy prescription of "laissez faire". Having missed the heated discussions and theories concerning planning, Keynesian macroeconomics, optimum taxation and various other fads and fashions, he could happily neglect the voluminous literature they spawned in the time he had been asleep.

But being of a curious bent he would probably have decided to read some condensed account of what had happened to the world while he was sleeping. He would have been astounded by the events of this century- of a world gone mad. He would have tried to find an explanation of what had gone wrong, and why and when the tide turned to enable the world economy to resume the progress which had stalled after he had gone to sleep. He would also wonder if the coming century would repeat the mistakes of the last, or if that age of universal worldwide peace and prosperity which seemed imminent towards the end of the great 19th century Age of Reform was now in prospect. These are the themes I will explore on Rip van Winkle's behalf in the rest of this essay. But before that I need to provide some harder evidence than Rip's casual empiricism for his belief that the world economy has picked up where it left off in the late 19th century.

I. REMEMBRANCE OF THINGS PAST

There are two pieces of statistical evidence which show that the world economy is back to where it was in the late 19th century. The first concerns the integration of global capital markets. The second the integration of world commodity markets 
through trade and thus indirectly the world markets for labor.

Determining the extent of global capital market integration has spawned a vast literature surveyed masterfully by Obstfield (1995). For our comparative historical purpose what we need is a statistical measure of this integration for which we can obtain historical data to see the trends in capital market integration over the last century. There are essentially two routes- a price and a quantity route. On the price measure, if capital markets were globally integrated, the price of an asset must be the same wherever it is sold. In practice it is very difficult to test this implication because there is insufficient data on identical assets in different markets. One data set that Obstfeld (1995) has used is the onshore-offshore price differential on a given asset. But the Euro currency markets which allow these comparisons are a post Second World War invention, and we cannot make similar historical comparisons.

The second route (via quantity) is based on the argument that in a completely integrated global capital market, as the productivity of a country's investment is not necessarily linked to the determinants of its savings rate, a rise in the latter should lead to their most efficient deployment world wide, which ceteris paribus should lead to a current account surplus and a capital outflow, and conversely if there is a rise in the productivity of a country's investment, to a capital account deficit and a capital inflow. This has been used by Feldstein and Horioka (1980) to argue that, in such a world, the savings and investment rates in a particular country should not be systematically associated. They suggest a cross section regression of the form :

$$
(I / Y)^{j}=a+b(S / Y)^{j}+u^{j}
$$

where $I / Y$ is the investment ratio; $S / Y$ the savings ratio, and $u$ a random disturbance for each country $j$. If capital is completely immobile $b=1$, so that the lower the value of $b$ from unity the greater the degree of capital mobility. 
There are various problems with the implementation and interpretation of these type of regressions ${ }^{5}$. But, despite this, as the data on savings and investment rates is readily available, faut mieux, at least an imperfect measure of capital market integration can be derived. There are moreover, two sets of data (with somewhat different countries covered) which allow us to obtain estimates of $b$ from the late 19th century to the present. These are those compiled by Taylor (1996) and Maddison (1991, 1992). Taylor has estimated the b coefficients for his historical data and we have done so for the Maddison data. The resulting values are charted in Fig.1 whose notes list the countries and the statistical significance of our estimates based on the Maddison data is given in Table 1. It also incorporates the estimated coefficients for a pooled sample of Taylor and Maddison countries.

A similar story emerges from all three trends in the $b$ estimates, which is in consonance with the qualitative historical evidence we have on changing capital mobility over this long period. ${ }^{6}$ What this shows is that till 1900 there was growing capital market integration, which was partially reversed in the early part of this century. There was a partial recovery in integration in the 1920's, but with the Great Depression and the Second World War there was further disintegration which continued into the post war period till the 60's. This was followed by some increased integration, but which did not become marked till the 1980 's. So that now the index is roughly where it was in 1870 when Rip went to sleep!

To determine the degree of globalization of commodity markets, we will use the historical data on real wage trends for a number of countries around the Atlantic basin which has been put together by Jeffrey Williamson and his collaborators.' The Hecksher-ohlin theory predicts that with growing integration of commodity markets through international trade there should be convergence in real wage rates as the low wages of the labor abundant countries rise towards those of labor scarce countries. 
Fig 2, charts an index of the dispersion of real wage rates (measured by the co-efficient of variation) for the time series for the Atlantic economies derived by Williamson (1995) from 1830 to 1986 for 15 countries (4 in the New World, and 11 in the Old). There is first the period till 1845 when there was a sharp divergence of real wages because of continuing trade barriers, high transport costs, and modest international labor migration. Then, second, after the Repeal of Corn Laws in Britain in 1846 and the subsequent creation of the first LIEO under British leadership there is a marked and continuing convergence in real wage rates that continues till 1900. This was the period during which Rip went to sleep, when there were sharp falls in transport costs ${ }^{8}$ and trade barriers, and free international migration of labor and capital. With the creeping protectionism at the end of the century this trend comes to an end. There follows the third period from 1900 and the Two World Wars, till about 1950, when there is a growing dispersion of real wages. This is the period in which the LIEO breaks down with the disintegration of world commodity and factor markets. The fourth period is the gradual reconstruction of a new LIEO under US aegis from about 1960 to the present, when convergence in real wages begins and continues till the early 1970 's, when there is a brief reversal (associated with the travails induced by the OPEC oil price shock) followed by continued convergence in the 1980s, so that the index is nearly back to where it was in 1900 .

As much of the convergence in the 19th century LIEO was fuelled as much by international labor migration as the integration of trade (see Williamson et al (1996)), the more recent convergence in real wages is more likely to have been due to trade integration, given the ubiquitousness of immigration controls limiting the international migration of labor.

It would seem therefore that Rip's casual empiricism is sound, and we can examine the three questions this rise, fall and rise of the LIEO over the last 150 years raises. 
II. WHY?

Broadly speaking the ghastly events of this century and the breakdown of the 19th century LIEO were due to the rise of various ideas which questioned the economic and political liberalism' that underlay the 19th century Age of Reform. In delineating them and to put them into historical and intellectual perspective some distinctions due to the English political philosopher Michael Oakeshott are useful.

Oakeshott makes a crucial distinction between two major strands of Western thought on the State: the State viewed as a civil association, or alternatively as an enterprise association. Oakeshott notes that the view of the state as a civil association goes back to ancient Greece. The state is seen as the custodian of laws which do not seek to impose any preferred pattern of ends (including abstractions such as the general (social) welfare, or fundamental rights), but which merely facilitates individuals to pursue their own ends. This view has been challenged by the rival conception of the state as an enterprise association -- a view which has its roots in the Judaeo-Christian tradition. The State is now seen as the manager of an enterprise seeking to use the law for its own substantive purposes, and in particular for the legislation of morality. The classical liberalism of Smith and Hume entails the former, whilst the major secular embodiment of society viewed as an enterprise association is socialism, with its moral aim of using the state to equalize people. Equally, the other major ideological challenge to classical liberalism in this century, Fascism (national socialism), also viewed the state as an enterprise association. Both bred collectivist moralities as a reaction to the morality of individualism.

Oakeshott (1993) notes that as in many other pre-industrial societies, modern Europe inherited a "morality of communal ties" from the Middle Ages. This was gradually 
superseded from the 16th century by a morality of individuality, whereby individuals came to value making their own choices "concerning activities, occupations, beliefs, opinions, duties and responsibilities" and also came to approve of this "self-determined conduct" in others. This individualist morality was fostered by the gradual breakdown of the medieval order which allowed a growing number of people to escape from the "corporate and communal organization" of medieval life.

But this dissolution of communal ties also bred what Oakeshott terms the "anti-individual", who was unwilling or unable to make his own choices. Some were resigned to their fate, but in others it provoked "envy,jealousy and resentment. And in these emotions a new disposition was generated: the impulse to escape from the predicament by imposing it upon all mankind" (p. 24)

This, the anti-individual sought to do through two means. The first was to look to the government to "protect him from the necessity of being an individual" ( $p$. 25) A large number of government activities epitomized by the Elizabethan Poor Law were devoted from the 16th century onwards "to the protection of those who, by circumstance or temperament, were unable to look after themselves in this world of crumbling communal ties" (p. 25)

The anti-individual, secondly, sought to escape his "feeling of guilt and inadequacy which his inability to embrace the morality of individuality provoked" (p. 25) by calling forth a "morality of collectivism", where "'security' is preferred to 'liberty', 'solidarity' to 'enterprise' and 'equality' to 'self-determination"' (p. 27) Both the individualist and collectivist moralities were different modifications of the earlier communal morality, but with the collectivist morality in addition being a reaction against the morality of individualism.

This collectivist morality inevitably supported the view of the state as an enterprise association. Whilst this view dates back to antiquity, few if any pre-modern states were able to be "enterprising", as their resources were barely sufficient to 
undertake the basic tasks of government-law and order and external defense. This changed with the creation of centralized "nation-states" by the Renaissance princes and the subsequent Administrative Revolution, as Hicks (1969, p. 99) has labelled the gradual expansion of the tax base and thus the span of control of the government over its subjects lives. Governments now had the power to look upon their activities as an enterprise.

There have been three versions of collectivist moralities Oakeshot.t identifies with the state viewed as an enterprise association. Since the truce declared in the 18th century in the European wars of religion, the major substantive purposes sought by states seen as enterprise associations are "nation-building" and "the promotion of some form of egalitarianism". These correspond to what Oakeshott (1993) calls the productivist and distributivist versions of the modern embodiments of the enterprise association, whose reliqious version was epitomized by Calvinist Geneva, and in our own times is provided by Khomeni's Iran. Each of these collective forms conjures up some notion of perfection, believed to be "the common good"..$^{10}$

Combining these insights with those of the great Swedish economic historian Eli Hecksher's Mercantilism, allows us to provide a thumbnail sketch of the rise fall and rise of economic liberalism during the last two hundred years.

The precursor of the 19th century LIEO was the system of mercantilism. It arose, as Hecksher has shown, from the desire of the Renaissance princes of Europe to consolidate their power by incorporating various feuding and seemingly disorderly groups which constituted the relatively weak states they inherited from the ruins of the Roman empire, into a "nation". This was a "productivist" enterprise in Oakeshott's terms. The same nationalist motive also underlay the very similar system of mercantilist industrial and trade controls that were established in much of the post war Third World. ${ }^{11}$ 
In the Third World, the jealousy, envy and resentment which bred the European anti-individualist, was based not merely on the dissolution of the previous communal ties that industrialization and modern economic growth entail, but also because in these post-colonial societies, such emotions were strengthened by a feeling amongst the native elites, of a shared exclusion from positions of power during the period of foreign domination. It is not surprising therefore that the dominant ideology of the Third World came to be a form of nationalism associated with some combination of the productivist and distributivist versions of the state viewed as an enterprise association. Historically, both these secular collectivist versions have led to dirigisme and the suppression or control of the market.

In both cases of "nation-building" (in post Renaissance Europe, and the modern Third and Second Worlds) the unintended consequences of the similar system of mercantilist controls instituted to establish "order" was to breed "disorder". As economic controls became onerous, people attempted to escape them through various forms of evasion and avoidance. As in 18th century Europe, in the post war Third World, dirigisme bred corruption, rent-seeking, tax evasion and illegal activities in underground economies. The most serious consequence for the State was an erosion of its fiscal base and the accompanying prospect of the unMarxian withering away of the state. In both cases economic liberalization was undertaken to restore the fiscal base, and thence government control over what had become ungovernable economies. In some cases the changeover could only occur through revolution -- most notably in France. ${ }^{12}$

But the ensuing period of economic liberalism during the 19th century's great Age of Reform, was short-lived in part due to the rise of another substantive purpose that most European states came to adopt -- the egalitarian ideal promulgated by the Enlightenment. Governments in many developing countries also came to espouse this ideal of socialism. The apotheosis of this 
version of the state viewed as an enterprise association were the communist countries seeking to legislate the socialist ideal of equalizing people. The collapse of their economies under similar but even more severe strains than those that beset less collectivist neo-mercantilist Third World economies is now history, though I cannot help remarking on the irony that it took two hundred years for 1989 to undo what 1789 had wrought!

III. WHEN?

If this account provides some reasons for the unravelling of the 19th century LIEO, as well for its subsequent resurrection gradually at first and more spectacularly in the last two decadesthe dating of this change is of some importance. The conference organisers want us to indicate what event or date marks an important turning point in this century. I would choose the OPEC coup of 1973. For its major unintended consequence was to set in motion various forces which undermined the intellectual consensus underpinning the dirigisme of most economies in the first two decades after the Second World War.

From the perspective of the Third World, the OPEC coup represented the ultimate politicisation of economic decisions in the global economy. By forming commodity cartels it was hoped that the resource rich countries of the developing world would hold the rest of the world to ransom. Demands arose for a new international economic order (NIEO) to replace the half baked LIEO which had been established in the wake of the collapse of the international system during the inter-war and 2nd world war period.

The partial restoration of the 19th century LIEO after the second world war was based on 3 pillars created as the outcome of the Bretton Woods conference: the IMF, World Bank and GATT. They were institutionalized attempts to resurrect three of the important elements of the 19th century LIEO which had collapsed in the early parts of this century: an international monetary system 
based on quasi-fixed exchange rates; flows of capital from developed to developing countries; the freeing of trade and payments regimes.

Of these the GATT was the most successful in resurrecting another LIEO. Under its auspices trade was progressively liberalized, which ushered in what has been termed the post war "golden age". But even while world trade boomed, most developing countries caught in the time warp of their import substitution strategies, did not reap its full benefits, claiming and getting their right to special privileges and exceptions in the emerging global free trade regime. The NIEO was their final attempt to replace this liberal trading order by one which was politically managed.

But within a decade the wind had gone from their sails. The supposed commodity power wielded by OPEC proved to be illusory. As market oriented economists had predicted, any attempt by a cartel to artificially raise the price of its product would eventually come unstuck. ${ }^{13}$ For such a price rise would first, induce a search for substitutes which would reduce the demand for the product, and second, lead to a search for alternative sources of supply. Both occurred. Various members of the cartel also succumbed to the temptation of increasing their share of the rationed output at the expense of the other members. Within a decade the oil price was no longer headline news. After the failure of another brief attempt at rigging it in the late 1970s, it has continued to decline in real terms ever since. ${ }^{14}$ This effectively killed the illiberal dream of the NIEO. GATT has now successfully transformed itself into the WTO after its latest Uruguay round, and developing countries are now its most loyal supporters.

In the monetary sphere, the IMF was created to supervise the new gold exchange rate system based on the adjustable peg. It replaced the 19th century gold standard which, as the events of the inter-war period had so painfully shown, could not be 
resurrected : essentially because of the inflexibilities in the workings of industrial labor markets, which did not permit the flexibility of domestic money wages and prices on which adjustments to economic shocks was predicated under the gold standard. The socialist "enterprise" association viewpoint was represented in the increasingly social democratic countries of the West by Keyensian prescriptions of aggregate demand management to maintain "full employment". Exchange rate changes were then deemed to be necessary when a country could only cut its real wages to achieve this target through a devaluation. The only country not permitted this 'luxury' was the US- because it formed the base of the gold exchange standard through its fixed parity with gold.

One consequence of the OPEC coup, which raised the costs of an essential input in all non-oil producing countries, and its partial monetary accommodation by most countries, was to raise their general price levels. At a time when the US was already suffering from the inflationary excesses associated with the financing of the Vietnam war, this further push to the inflationary process (and the stagnation in output that accompanied it) made the US balance of payments unviable. A devaluation was required to realign its domestic with the international price level. This was achieved by President Nixon's closing of the gold window, which in turn inflicted the coup de grace to the gold exchange standard. The subsequent period has seen the institution of a world wide free floating exchange rate regime among the major economic powers, which has made it unnecessary to use dirigiste means to manage the balance of payments. This was the first benefit from the OPEC coup.

It also undermined the original mandate of the IMF, which has since, like Pirandello's " Six characters in search of an author", been looking around for a play. It has skillfully found a role in the ongoing adjustments from the plan to market underway in both the Third and second worlds. But this has a natural limit. The IMF's future cannot be bright, particularly (as argued below) 
in light of its most recent actions in South East Asia.

The second benefit from the OPEC coup was that, the

ensuing stagflation exposed the fallacies of Keynesian macroeconomics. Gradually all Western governments realized that full employment could no longer be maintained by spending other peoples money. The classical prescriptions of sound money and deregulated labor markets (along with other supply side measures) were the only way to deal with stagflation.

The third consequence, and the most momentous for the Third World, arose from the disposition of their new found oil wealth by the sparsely populated countries of the Middle East. The inter-war collapse of world capital markets which involved many defaults by third world borrowers led to their subsequent exclusion from western capital markets: through exchange controls which were ubiquitous in Europe -with the UK only abolishing them in 1979- and legal restrictions eg. the 'blue sky' laws in the US. The World Bank, or IBRD as its initial and still major component is called, was set up as a financial intermediary to fill this lacunae. Its intergovernmental ownership and guarantees allowed it to borrow at preferential rates in developed country markets and on-lend the money at near commercial interest rates to the Third World. For those countries deemed too poor to borrow at these rates a soft loan window the IDA- was established with money subscribed by Western governments. These governments had also established their own bilateral foreign aid programs, mainly to compete for political influence in the Third World during the Cold War, than to serve their professed aim of alleviating world poverty. As nearly all of these capital flows were mediated through multilateral or bilateral governmental channels, the access of developing countries to world capital markets was necessarily politicized. This was in stark contrast to the 19th century pattern when private capital flowed from Europe to the rest of the world on market principles.

The OPEC coup set in train a chain of events which were 
to dramatically change this post war politicisation of the disposition of international capital. The OPEC countries could not conceivably absorb the large surpluses derived from the oil price rise domestically. They had to place them abroad. As Third World capital markets were underdeveloped, this in effect meant the West. But having obtained their new found wealth through a political coup, the OPEC countries were fearful of placing it within the reach of government's whose citizens they had robbed. It could be confiscated: a not unreasonable fear as shown by the subsequent sequestration of Iranian assets by President Carter. So they placed their money in the off-shore branches of the money center banks (the so called Eurocurrency market). These off-shore banks had developed outside the jurisdiction and reach of their parent monetary authorities and governments in the $1960 \mathrm{~s}$ to allow intermediation of capital flows to communist Europe - which had been equally wary of dealing directly with institutions which would be subject to political pressure from its cold war adversaries.

The consequent explosion in the liquidity of these Western off-shore branches led them to a frantic scramble to onlend this money. This recycling of the OPEC surpluses, was also pressed by their governments, who were concerned by the worldwide deflationary consequences of an increase in the worldwide savings propensity caused by the transfer of income from relatively low to high savings propensity countries that the Opec coup entailed. There were many eager borrowers in the Third World, in particular in the "inward looking" countries of Latin America. Thus the seeds of the debt crisis were sown.

This bank lending to the Third World was based on variable interest rates linked to LIBOR. When, in the late 1970's, the US and subsequently much of Europe adopted sound money policies to deal with the stagflation that had plagued them since the OPEC coup, world interest rates and the cost of servicing debt rose dramatically. As most of the Third World borrowers - mainly 
in Latin America but not in East Asia- had borrowed to deal with their longstanding fiscal deficits, they now found themselves unable to service their debts. Starting with Mexico many in effect defaulted on their obligations. They were forced to recognize- as had the mercantilist states in the past- that the only way to restore their diminished control over the economy was through economic liberalization. Thus began the long drawn out process of reform whereby dirigiste "inward looking" regimes are gradually being replaced by more market friendly "outward looking" ones, all over the globe.

Economic liberalization has also provided many developing countries a new- found access to direct foreign and portfolio investments. For them this is a more desirable form of borrowing than bank borrowing at variable interest rates, because the associated currency and income risks are shared with the foreign investors. More sustainable forms of capital flows are thus now available to developing countries willing to change their nationalist attitudes to multinationals. ${ }^{15}$ These market based capital flows now dwarf the politicized flows from bilateral and multilateral agencies- whether they be IBRD loans or various forms of foreign aid.(see Fig. 3) The future of this politicized part of the world capital market is increasingly in jeopardy. ${ }^{16}$

Finally, the stagflation resulting from the OPEC coup also led to the replacement of demand management by supply side policies in most developed countries. Beginning with the Thatcherite revolution in the UK, the worldwide movement towards privatization, and deregulation - in particular of labor marketsis reversing nearly century old trends and the habits and intellectual beliefs they had engendered. With the spectacular collapse of the Communist economic system, ${ }^{17}$ dirigisme for the first time in a century is in worldwide retreat. It is a supreme irony that the unintended consequences of the final push to set up a politicized planned global economy initiated by the 1973 OPEC 
coup should have instead led to this new era of economic liberalisation.

IV. WHAT NEXT?

What of the future? Is this new world wide "Age of Reform" likely to be more permanent than its 19th century predecessor? There are auguries- both favorable and unfavorable.

(1) Fears: To take the latter first. The desire to view the State as an enterprise association still lingers on, as part of social democratic political agendas in many countries. It has ancient roots and is unlikely to die. It has now adopted a new voice, which Ken Minogue ${ }^{18}$ has labelled "constitutional mania". This emphasizes substantive social and economic rights in addition to the well-known rights to liberty --freedom of speech, contract, and association -emphasized by classical liberals. It seeks to use the law to enforce these "rights" based partly on "needs", and partly on the "equality of respect" desired by a heterogeneity of self-selected minorities differentiated by ethnicity, gender and/or sexual orientation. But no less than in the collectivist societies that have failed, this attempt to define and legislate a newly discovered and dense structure of rights (including for some activists those of non-human plants and animals) requires a vast expansion of the government's power over people's lives. Their implementation moreover requires -- at the least -- some doctoring of the market mechanism. Then there is the global environmental scare and the population scare. Finally the UN has taken up the cause of the world's poor and is seeking to establish a worldwide welfare state through a UN economic security council. Classical liberals can clearly not yet lay down their arms!

Equally worrying is the "Delors" vision of Europe which seems to be a form of mercantilist nation- building, in the manner 
of the Renaissance princes documented by Hecksher. ${ }^{19}$ Many voices are also resurrecting the threat from pauper labor imports to US and European living standards (particularly of the low skilled), and thence their social harmony. This is particularly worrying as it echoes various fears in the late 19th century of the social disruptions and discontent caused by the Industrial Revolution. Though recent historical work has questioned the bleak picture painted by novelists such as Dickens ${ }^{20}$, their fears were nevertheless influential in propagating the dirigiste cause, which led to the gradual unravelling of the 19th century LIEO as the distributive consequences of trade integration led to the rise of protectionist political coalitions in the US, Germany and France after $1870 .{ }^{21}$

Another great structural change is taking place in Western economies, whose short term consequences could be equally painful and trigger another dirigiste reversal of the emerging LIEO. It maybe worth spelling this out. Hicks saw the substitution of fixed for circulating capital as the distinguishing feature of the Industrial Revolution. ${ }^{22}$ But, as Ricardo in his chapter on "Machinery" noted, during the period of adjustment there could be a reduction in employment and output; though at the end of the process the productive power and hence the level and growth rate of output and employment would be higher. This explains why it took a long time in Britain for the Industrial Revolution to raise overall living standards, and why during the period of adjustment, the older handicraft workers (using circulating capital in various forms of the 'putting out' system) initially suffered, until they were eventually transformed into much richer industrial workers.

Today a similar process is underway in the West, with the increasing substitution of human for fixed capital in its newly emerging "information age" service economies. This process has been accelerated by the emerging LIEO as the unskilled labor rich countries of Asia -particularly China and India-go through their own Industrial revolutions, and increasingly specialize in the 
production for export of those manufactures on which workers particularly the low skilled- had depended in the past in the West. The ongoing substitution of human for fixed capital is an unavoidable means for maintaining and raising living standards in the west. But during the process of adjustment it may cause severe social strains.

In this adjustment process it is inevitable that initially the premium on human capital should rise, as this provides the signal for workers to upgrade their skills. This rising skill premium accompanied by stagnation in the wages of the unskilled is evident in all western countries. Those countries, mainly in Europe, which have prevented this signal from working, have found that, instead of low and stagnant wages for the unskilled they have the much worse problem of high and rising unemployment. Despite the siren voices calling for protection from Third world imports to ease these problems, for the West to follow their advice would be a snare and a delusion. But, as the rise of protectionism based on the equally deluded infant industry arguments of Hamilton and List in the late 19th century demonstrates, such snares are not always avoided. At a time when the Third and second worlds have enthusiastically embraced the LIEO it is the temptation for harried Western governments to turn their backs on the world they have created which constitutes the greatest threat to the future of the new global LIEO. ${ }^{23}$

Then, there is the creeping and continuing dirigisme to promote various "social policies" in many Western states (including the US). These include demands for the inclusion of environmental and labor standards in the wTO (which has replaced GATT), as well as recent attempts to thrust western moral values (democracy and human rights) down foreign throats- using the threats of unilateral trade restrictions. All these inevitably poison international relations. The nagging bad temper that is generated could lead to a gradual erosion of the liberal international economic order, as in the late 19th century. 
Meanwhile there are more immediate worries that the recent financial crises in Asia might lead to a backlash against the globalisation of capital flows in developing countries. ${ }^{24}$ There is a pervasive fear in the Third world that continuing capital market liberalisation will lead to a greater volatility in their national incomes damaging growth performance. The recent Asian crisis which has taken the stripes off so many of the region's tigers has merely accentuated these fears. Mahathir's recent reimposition of stringent capital controls in Malaysia maybe the harbinger of a trend towards the resucitation of economic nationalism.

This fear of volatility is an ancient worry of the Third World, earlier expressed as the purported adverse effects on growth of the export instability engendered by primary product exporting countries integration in the world economy. ${ }^{25}$ In the 25 country study covering the period since the 2nd World War, Myint and I could find no statistical evidence that the volatility of annual growth rates effected overall growth performance- a conclusion in consonance with the numerous studies of the effects of export instability on growth. Thus Hong Kong has had one of the most volatile growth rates amongst developing countries, while India one of the most stable- but the long run growth performance of Hong Kong puts the Indian one to shame. Thus though there may undeniably be greater volatility in national incomes of countries integrating with the world economy, this need not damage their long run growth rates.

But what of the lessons against globalisation many in the Third World seem to be drawing from the recent Asian crisis? This appears to be a misreading of the causes of the crisis, and how future ones can be avoided. There were three main causes of the crisis: (i) the exchange rate regime; (ii) the moral hazard in the domestic banking systems caused by the 'Asian model'; (iii) the international moral hazard created by the actions of the IMF.

To elaborate and explain. The first cause was the quasi fixed exchange rate regimes in many of the countries. It is 
increasingly becoming clear that with a globalized capital market only two exchange regimes are viable: a fully floating exchange rate or a rigidly fixed rate one as in the currency board of Hong Kong. ${ }^{26}$ The reason is that, these are the only ones which allow automatic adjustment to external and internal shocks without any need for discretionary action by the authorities. ${ }^{27}$ In a world which requires instantaneous responses to the actions of a highly decentralized but integrated world capital market mediating these shocks, the authorities do not have the time or the means to obtain the requisite information to deal with these shocks in a centrally planned manner. They often end up by being the problem rather than the solution if they try to manage their exchange rates in this volatile and unpredictable world economy, leading to serious misalignments of the real exchange rate. ${ }^{28}$ An automatic adjustment mechanism is therefore preferable to a discretionary one.

The second cause was a systemic flaw in the 'Asian' model of development. A central feature of this model- as seen most clearly in Korea but presaged by the development of Japan -is a close linkage between the domestic banking system, industrial enterprises (particularly the biggest) and the government. The fatal flaw in this 'Asian model'- as shown by the recent travails of both Korea and Japan- is that, by making the banking system the creature of the government's will, it creates tremendous moral hazard in the domestic banking system. The banks have no incentive to asses the credit worthiness of their borrowers or the quality of the investments their loans are financing, as they know- no matter how risky and over extended their lending- they will always be bailed out by the government. This can lead in time to a mountain of bad paper and the defacto insolvency of a major part of the banking system, as has happened in both Korea and Japannot to mention the corruption that is inevitably involved in this type of development. But as the example of the US savings and loans crisis shows this collapse of the banking system can 
ultimately be cleared up if there is the political will. Korea does have the will, and should bounce back fairly shortly. By contrast, Japan, which inherited a political system based on institutionalizing political paralysis from the Meiji oligarchs, shows no sign as yet of grasping this nettle and its prospects must therefore remain a cause for continuing concern.

Third, the problem of moral hazard for the domestic banking system created by this 'Asian' model have been aggravated by the actions of the IMF and the entrance of foreign bankers as lenders in the newly liberalized capital markets. Of the three types of capital flows that can be distinguished - direct foreign investment, portfolio investment and bank lending- the income and foreign currency risks of the first two types of flows is shared by both the lender and the borrower, as the 'investments' are denominated in domestic currency. By contrast foreign bank loans are usually denominated in dollars and the interest rate is linked to LIBOR. This means that, if faced by a shock which requires a devaluation (in a floating rate regime) the domestic currency burden of the foreign bank debt rises pari passu with the changing exchange rate. If this debt is incurred by the private sector, this rising short term debt burden need pose no problem for the country. For, if the relevant foreign banks run, the borrowers can always default on their debt.

But now enter the IMF. The foreign banks faced by a default on their Third World debt have ever since the 1980's debt crisis argued that this poses a systemic risk to the world's financial system, and asked in effect for an international bailout to prevent this catastrophe. Since the 1980's debt crisis and most clearly in the Mexican crisis in the early 90's and the recent Asian crisis, the IMF has been more than willing to oblige, as since the demise of the Bretton Woods system it has been searching for a new role. With the debt crisis of the 1980's and the more recent Mexican and Asian crises it has increasingly become the international debt collector for foreign money center banks, as 
well as an important tool of US foreign policy.

The crisis in Indonesia provides the clearest example of this metamorphosis of the Fund. Before the Thai crisis hit the region the Indonesian economy had been fairly well-managed despite the 'cronyism' of its capitalism. It had provided exceptional growth rates, with a sensible deployment of its oil revenues unlike many other comprators eg. Nigeria- and which had made an impressive dent in its mass poverty. At the time of the Thai crisis, its economic fundamentals were sound: it did not have a massive trade or budget deficit, it had a flexible exchange rate, its debt burden was not onerous and its foreign bank debt was all private.

When the contagion from Thailand spread, the foreign banks (mainly US and Japanese), which had made loans to the Indonesian private sector, ran, leading to a depreciation of the rupiah and a massive increase in the domestic currency costs of servicing this short term debt. Many of the borrowers would then have defaulted, and that would have been that. But enter the IMF. Under pressure from the governments of the foreign banks it deemed that such private sector defaults would pose a risk to the world's financial system, and under the cover of an IMF program, the Indonesian government was in effect forced to take on these private debts. The money from the IMF paid off the foreign lenders, and the general taxation of the Indonesian populace will have to repay the IMF. The Indonesian people have thus through the aegis of the IMF bailed out the foreign banks.

These actions of the IMF -ever since the 1980's debt crisis-have generated serious moral hazard in foreign bank lending. With the increasingly confident expectation that they will be bailed out via the IMF no matter what the quality of their lending to Third World countries, foreign banks have no incentive to act prudently in their foreign lending. ${ }^{29}$ When this international moral hazard is coupled with the domestic moral hazard associated with the politicized domestic banking systems of 
the 'Asian' model -as in Korea- there is double jeopardy. Foreign banks lending to domestic banks which know they will be bailed out will over-lend, leading to ropy investments and an eventual debt crisis for the country.

With measures to remove the domestic moral hazard being widely adopted in the region, the international moral hazard from the IMF's operations would still remain. What is to be done? The best solution would be to shut down the IMF. It's original mandate ended with the Bretton Woods exchange rate system. Since then its continuance, though in the interests of its rent-seeking international bureaucrats, is no longer in the interests of the world economy.

Being realistic it is unlikely that the IMF will be shut down- after all the redundant UNESCO, ILO and UNIDO have not been, even though their major financiers at some stage sought to do so. In the circumstances, to avoid the socialisation of the private risks associated with volatile foreign bank lending in the presence of this international moral hazard is for local central banks to ensure that all such borrowing is suitably hedged. If they lack the requisite capital markets for such hedging some of them might consider a second best 'control' on such capital flows till these markets are developed. This would lay down that all short run foreign bank loans taken out by residents must be denominated in local currency. By raising the costs of such borrowing this will be eqivalent to a market determined tax on such flows. Second, it would mean the foreign banks would now have to share in the foreign exchange risk, and at times of contagion instead of running might pause and refinance their long term viable borrowers.

(2): Hopes : Against these dangers there are many hopeful signs. As in pre-modern times, today's states are finding it more and more difficult to find the resources to continue (or increase) their enterprise. This is partly because of the world wide growth in tax-resistance, ${ }^{30}$ and most important the 
virtually complete integration of international financial markets. The latter has strengthened the former. Nor is a reimposition of exchange controls to stop this process likely, if for no other reason than that it would now have to be adopted and enforced worldwide.

The instincts of the state through most of human history have been predatory. The integration of world financial markets provides a bulwark against these base instincts- like tying Ulysses to the mast. Every government is now concerned about the rating of its country and its enterprises by world capital markets. Bad policies- or at least those disapproved of by world capital markets- can lead to an instantaneous reduction in a country's wealth, and the terms on which it can acquire the means to increase it- a painful lesson many SE Asian countries have recently learnt. The worldwide movement towards fiscal rectitude and the creation of an economic environment which is transparent and rewards efficiency is no longer a matter of choice but necessity. With massive global flows of capital triggered at the press of a button, government's are now faced with an instantaneous international referendum on their economic policies. The Central Bank or Treasury proposes but the money market disposes!

The same actual or incipient fiscal crisis which has ultimately prevented the state from giving in to the "enterprise" voice, or led to forced reversals in its past dirigisme, also threatens the major form of its continuing enterprise in the Westthe welfare state. The partial dismantling of the New Zealand welfare state and its continuing erosion in that social democratic beacon of hope, Sweden, are surely more than straws in the wind. ${ }^{31}$ Finally, there is the recent spectacular movement

from the plan to the market in China and India. The future progress of these ancient civilizations raises unresolved questions about the relationship between culture, democracy and development. ${ }^{32}$ Can the market survive in polities which are 
undemocratic? Will globalization necessarily lead to the worldwide spread of a homogenized Western culture ? On the latter I have my doubts, partly because the very mainspring of Western culture-its individualism- is paradoxically leading to social decay and decadence in the West. ${ }^{33}$ There is a triumphalist tendency in the West, most noticeable in the US, to identify its own cultural and political forms as necessary conditions for its economic success. This raises complex issues which I cannot go into on this occasion. ${ }^{34}$ There is, however, one point which needs to be stressed, and that concerns the first of the questions posed in this paragraph. Many, including the major contemporary advocate of the classical liberal order - Hayek ${ }^{35}$ - have posited a necessary connection between economic and political liberty (nowadays translated into the market cum democracy). I disagree. 36 Oakeshott's distinction between a civil and enterprise association is more useful in judging the sustainability of a market order. For after all, till 1997, the only "country" which was clearly a civil rather than enterprise association- in Oakeshott's terms- was Hong Kong, and it was a colony, now extinguished!

Given these contradictory trends in the global economy, I think we can be certain that the Polyannish hopes of an "end of history" are premature. Mankind is unlikely in the next millennium, no less than in the past, to escape the ancient Chinese curse : "May you live in exciting times". 
REFERENCES

F.Aftalion (1990): The French Revolution- An Economic Interpretation, Cambridge Univ. Press.

F.Hayek (ed) (1954): Capitalism and the Historians, Rout ledge.

F.Hayek (1973, 1976, 1979): Law, Legislation and Liberty, 3 vols., Routledge.

E.Hecksher (1955): Mercantilism, 2 vols., Allen and Unwin.

M.Feldstein and C.Horioka (1980):"Domestic Saving and International Capital Flows" Economic Journal, vol.90, June, ps. 314-29.

M.Goldstein et al (1993): International Capital Markets , International Monetary Fund, Washington D.C.

London.

F.A.Hayek (1954): Capitalism and the Historians, Routledge,

F.A.Hayek (1976/78): Denationalisation of Money, Institute of Economic Affairs, London.

F.A.Hayek (1979): Law, Legislation and Liberty, University of Chicago Press, Chicago.

E.Hecksher (1955): Mercantilism, 2 vols., 2nd rev.edtn., Allen and Unwin, London. Press.

J.R.Hicks (1969): A Theory of Economic History, Oxford Univ.

D.Lal (1975) : Appraising Foreign Investment in Developing Countries, Heinemann Educational Books, London.

D.Lal (1978) : Men or Machines, ILO.

D. Lal (1983/1985/1998) : The Poverty of 'Development Economics', Institute of Economic Affairs, London; Harvard University $'$ Press, Cambridge, Mass, 1985; 2nd revised and expanded edtn., Institute of Economic Affairs, London.

D.Lal (1993): The Repressed Economy, Economists of the 20th 
century series, Edward Elgar.

D.Lal (1994): Against Dirigisme, ICS Press.

D.Lal (1996): "Participation, Markets and Democracy" in M.Lundahl and B.J.Ndulu (eds): New Directions in Development Economics, Routledge.

D.Lal (1996a): "Foreign Aid: An idea whose time has gone", Economic Affairs, Autumn 1996, ps. 9-13.

D.Lal (1998): Unintended Consequence: Factor Endowments, Culture and Politics: On Economic Performance in the Long Run, MIT.

D.Lal (1998a): Renewing the Miracle: Economic Development and Asia, Inaugural Harold Clough lecture, Institute of Public Affairs, Perth, July 1998.

D.Lal (1998b): "Taxation and regulation as barriers to international investment flows", paper for Mont Pelerin Society Golden Anniversary meeting, Washinton DC, Aug.1998.

D.Lal and H.Myint (1996): The Political Economy of Poverty, Equity and Growth, Clarendon Press.

A.Maddison (1991): "A long run perspective on saving", University of Groningen, mimeo.

A.Maddison (1992): "A Long-run perspective on saving", Scandinavian Journal of Economics, vol. 94, no.2, ps. 181-96.

K.Minogue (1993): The Constitutional Mania, Policy studies No.134, Center for Policy Studies, London.

B.R.Mitchell (1992): International Historical Statistics:Europe, 1750-1988, Stockton Press, New York.

M. Oakeshott (1973): On Human Conduct, Clarendon Press.

M. Oakeshott (1993) : Morality and Politics in Modern Europe, Yale Univ. Press.

M.Obstfeld (1995): "International Capital Mobility in the 1990's" in P.B.Kenen (ed): Understanding Interdependence, Princeton Univ. Press, Princeton, N.J. ps. 201-61.

K.H.O'Rourke, A.M.Taylor and J.G.Williamson (1996): "Factor Price Convergence in the Late 19th century", International Economic Review, vol.37, no.3, ps.499-530. 
K.H.O'Rourke and J.G.Williamson (1994): "Late 19th century Anglo-American Factor Price Convergence: Were Hecksher and Ohlin Right?", Journal of Economic History, vol.54, ps. 892-916.

R.Rogowski (1989): Commerce and Coalitions, Princeton Univ. Press, Princeton, N.J. York.

R.Rosecrance (1986): The Trading State, Basic Books, New

R.Rosecrance (1996): "The Virtual State", Foreign Affairs

A.K.Sen (1992): Inequality Reexamined, Harvard Univ. Press.

R. Sugden (1993): "A Review of Inequality Reexamined by Sen", Journal of Economic Literature, Dec.

A.M.Taylor (1996): "International Capital Mobility in History: The Savings-Investment relationship", NBER Working Paper, No. 5743, Sept., mimeo.

J.G.Williamson (1995): "The Evolution of Global Labor Markets since 1830: Background evidence and hypotheses", Explorations in Economic History, vol. 32, ps. 141-96.

J.G.Williamson (1996): "Globalization, Convergence and History", The Journal of Economic History, vol.56, June, ps. 277306 .

M. Wolf (1994): The Resistible Rise of Fortress Europe, Rochester paper No.1, Trade Policy Unit, Center for Policy Studies, London. 
ENDNOTES

1. see Lal (1996), (1998)

2. I assume that Rip van winkle was a male, but in this politically correct, androgenous age, if the reader likes whenever I write 'he' that should also imply 'she'.

3. Rosecrance ( ), (1996)

4. see Williamson, Lal (1995)

5. see Obstfeld (1995) for details.

6. see Taylor (1996) p.13 for details and references. For the current period see Obstfeld (1995) and Goldstein (1993).

7. see Williamson (1995), O'Rourke, Taylor and Williamson (1996), and Williamson (1996) for an overview.

8. O'Rourke et al (1996)p.509, find that between 1870 and 1910, freight indices for railroads and ocean shipping dropped from 41 to 53 per cent. This lead to considerable price convergence for tradeable. O'Rourke and Williamson (1994) find the spread between grain prices in Liverpool and Chicago fell from 60 per cent in 1870 to 14 per cent in 1912; for meat and animal fats from 93 to 18 per cent, iron products from 80 to 20 per cent and cotton textiles from 14 to 1 per cent over the same period.

9. I use the term "liberalism" in the sense of classical liberalism and not in its current American sense, where it has become synonymous with some forms of socialism.

10. Sugden in his review of Sen, makes much the same distinction 
between the two divergent views of public policy embodied in the technocratic "market failure" school and those of the neoAustrians and the Virginia public choice school.

11.See Lal-Myint (1996) Chp.7 on which much of this section is based.

\section{See Aftalion.}

13. The one contemporary cartel which has bucked this trend is the diamond cartel run by De Beers which was originally created by Cecil Rhodes. See "The Diamond Business", The Economist, Dec. 20th 1997, ps. 113-15, for an account of how this has been done, and why it might come unstuck in the future.

14. Having risen from $\$ 4$ in 1972 to $\$ 30$ in 1983, it collapsed in 1986 and is now about $\$ 20$.

15. The costs and benefits of direct foreign investment are outlined and case studies for India and E.Africa presented in Lal (1975).

16. see Lal (1996a).

17. It is still unclear to what extent the collapse is due to the internal factors resulting from the economic consequences of past dirigisme which impels reform (see Lal(1987)), or external factors such as the threat of star wars which upped the ante in terms of unsustainable defense expenditures for the Soviet Union. Certainly Deng's reforms in China were motivated by a threatened internal economic collapse rather than any external factors.

18. see Minogue (1993)

19. see Wolf (1994)

20. see Hayek (1954)

21. see Rogowski (1989).

22 . see Hicks (1969) esp. the Appendix, and Lal (1978), Appendix A. 23. This fear is also echoed by Williamson (1996)

24. The remainder of this section is based on Lal (1998a, b). 25. see Lal (1983).

26. The reason why the Hong Kong currency board seems to be under 
some threat at the time of writing (Sept.1998) is because of the inappropriate actions taken by the authorities which broke the rules of the currency board. These actions were unsuccessfully aimed at propping up the Hong Kong property market, but in the process have raised doubts about the continuing credibility of the Hong Kong authorities commitment to the fixed peg of the exchange rate.

27.see D.Lal: The Repressed Economy, Economists of the 20th Century series, Edward Elgar, Aldershot, 1994, Chp. 6.

28. The real exchange rate $\left(e^{r}\right)$ is defined as the relative price of non-traded $\left(\mathrm{p}^{\mathrm{n}}\right)$ to traded goods $\left(\mathrm{p}^{t}\right)$. As the nominal exchange rate (e) effects the price of traded goods given their foreign currency price $\left(\mathrm{p}^{\mathrm{F}}\right)$, the real and nominal exchange rate are linked by the relationship: $e^{\mathrm{r}}=\mathrm{p}^{\mathrm{n}} / \mathrm{p}^{\mathrm{t}}=\mathrm{p}^{\mathrm{n}} / \mathrm{e} \cdot \mathrm{p}^{\mathrm{f}}$. An inappropriate nominal exchange rate (e), can lead to a misaligned real exchange rate $\left(e^{r}\right)$.

29. The refusal of the IMF and the Group of Seven to bail out the foreign lenders in the most recent Russian crisis may however show that at last this danger is being recognised.

30. Though in a rearguard action the OECD has just announced a task force which will study how to prevent tax competition between states which is rightly feared to be eroding the ability of states to extract the maximum revenue from their citizens. But whether one should applaud this attempt to create a cartel of predatory states to maximize the exploitation of their prey depends upon whether one sides with the predator or the prey. But even if such a cartel could be formed it would be subject to the form of cheating which undermined the OPEC cartel, for instance: some country or other would find it in its interests to attract mobile factors of production with the inducement of lower taxation. By so openly avowing the cause of the predatory states which control its purse strings the OECD would seem to have signed its death warrant in the eyes of economic liberals.

31. I may claim some foresight in seeing trends earlier than most others. See Chps. 8 and 15 in Lal (1993).

32. I deal with some of these in my 1995 Ohlin lectures, Lal (forthcoming).

33. see Lal (1998) for details and substantiation.

34. But see Lal (forthcoming)

35. see Hayek (1979). 
36. see Lal (1996) 


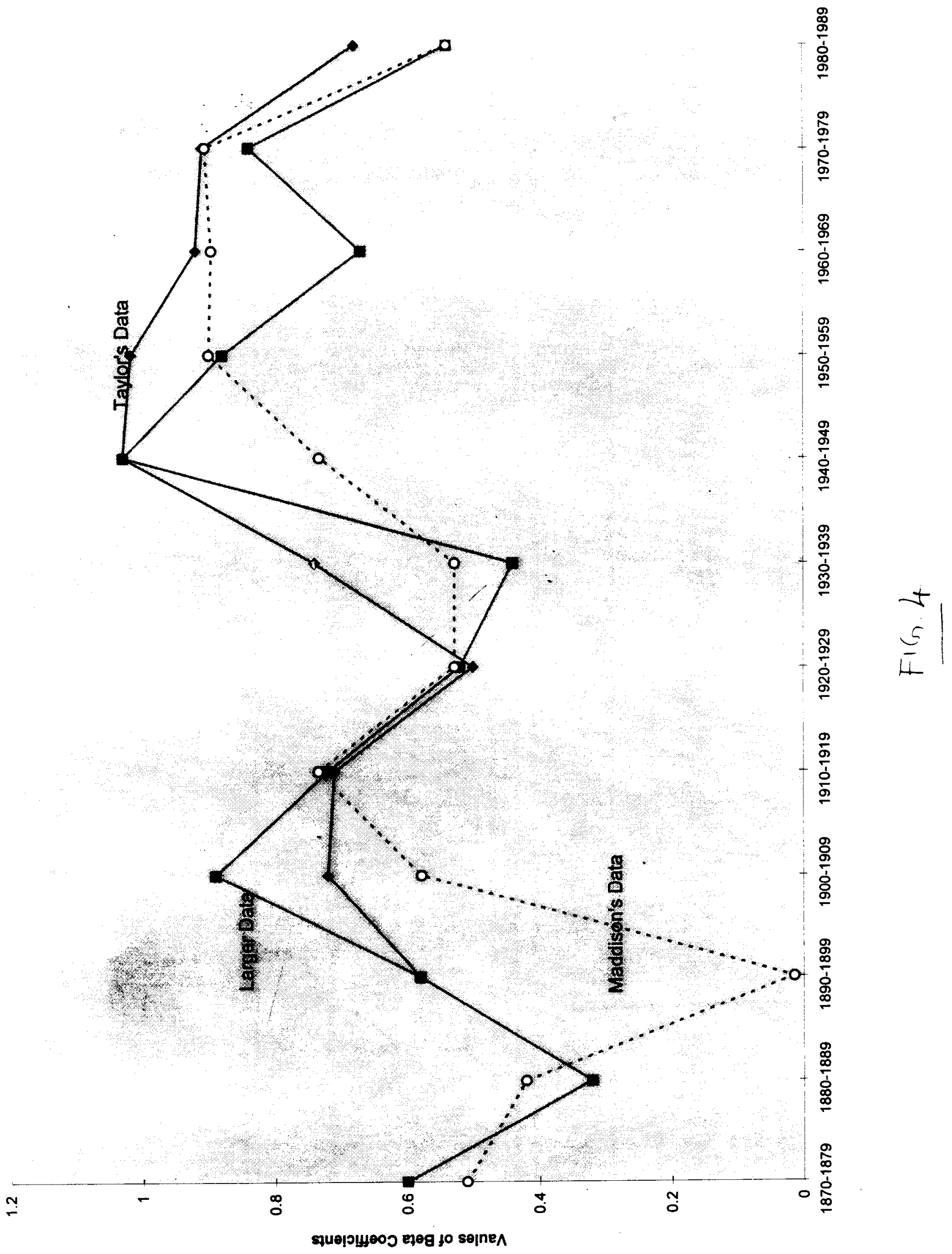


$\left(2-f^{2}\right)$

$-1$

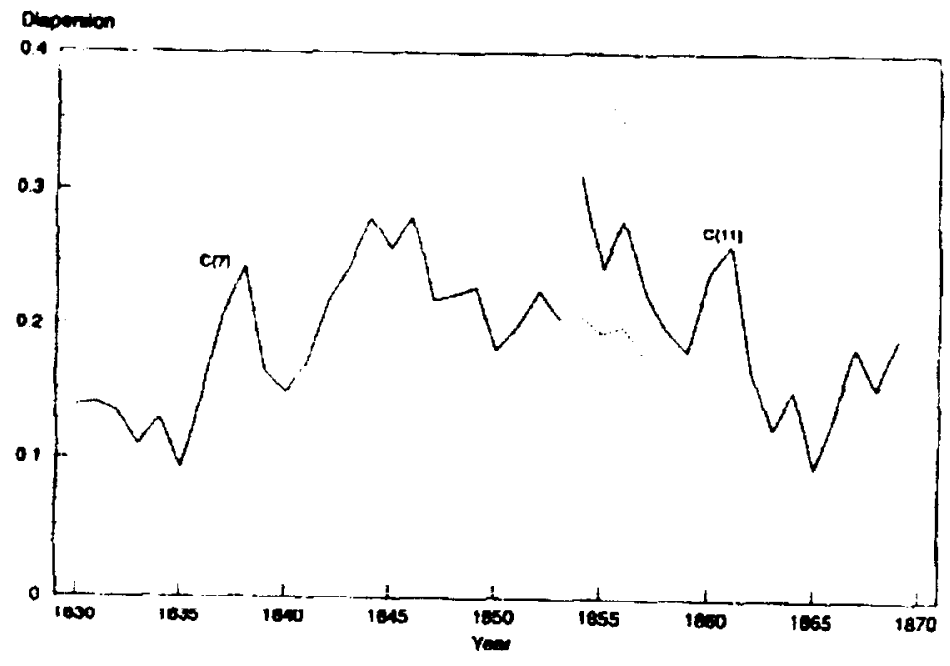

International real wage dispersion. 1831)-1869.
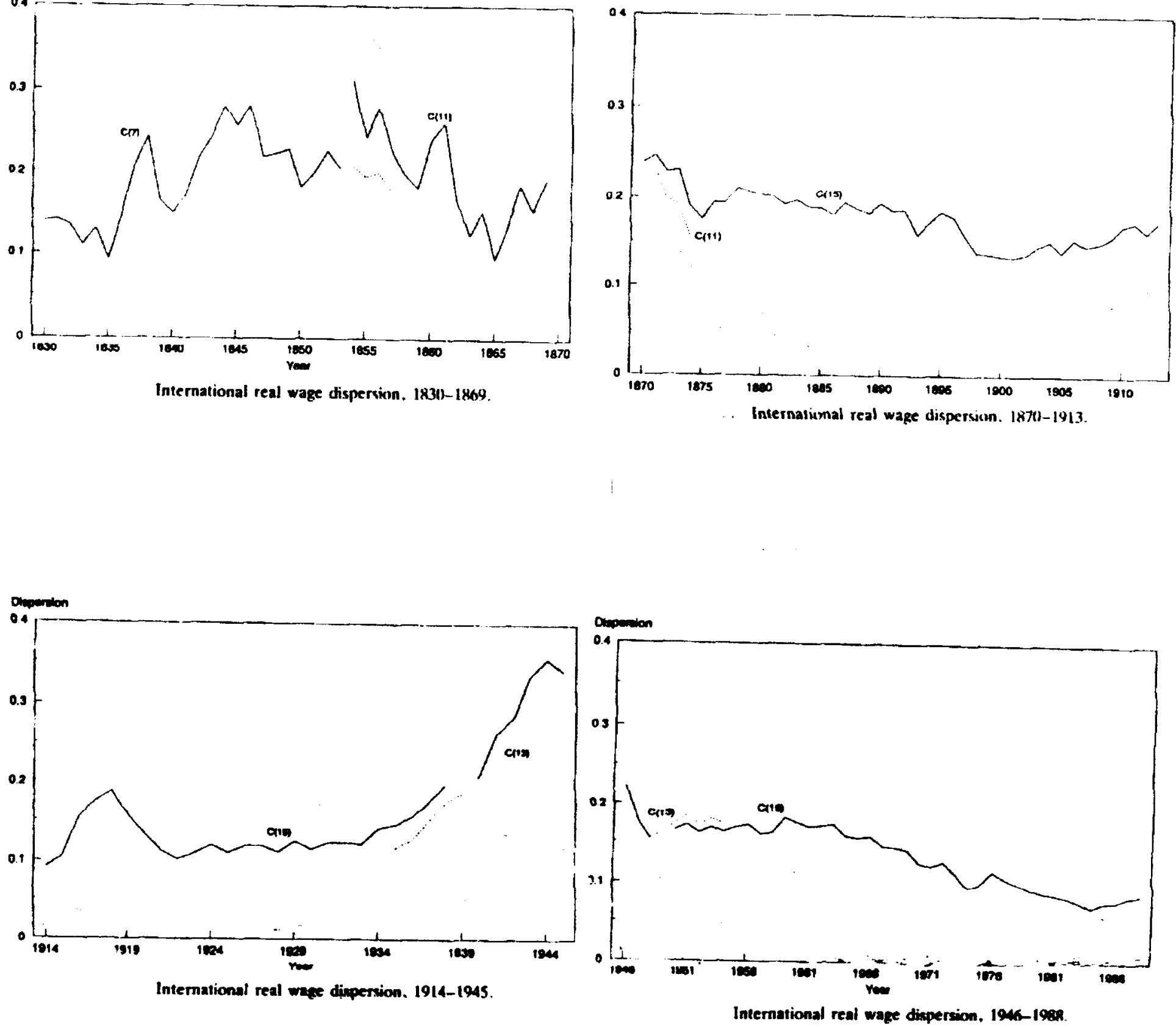

Fig 2

Source: Williamson (1995) 


\section{Comparison of Beta Coefficients}

\begin{tabular}{|c|c|c|c|c|}
\hline & Taylor's & \# of OBS & Larger Data & \# of OBS \\
\hline $1870-1879$ & $0.6(1.98)$ & 10 & same & 10 \\
\hline (Missing Data) & Arg \& Jpn & & Ind, Kor, Neth, Twn & \\
\hline $1880-1889$ & $0.32(1.6)$ & 12 & same & 12 \\
\hline (Missing Data) & Arg \& Jpn & & Ind, Kor, Noth, Twn & \\
\hline $1890-1899$ & $0.58(3.77)$ & 12 & same & 12 \\
\hline (Missing Data) & Arg \& Jprr & & Ind, Kor, Neth, Twn & \\
\hline $1900-1909$ & $0.72(2.92)$ & 12 & $0.89(4.9)$ & 15 \\
\hline (Missing Data) & & & Neth & \\
\hline $1910-1919$ & $0.71(3.63)$ & 12 & $0.72(4.93)$ & 15 \\
\hline (Missing Data) & & & Neth & \\
\hline $1920-1929$ & $0.5(2.87)$ & 12 & $0.52(3.9)$ & 16 \\
\hline $1930-1939$ & $0.74(5.82)$ & 12 & $0.44(2.48)$ & 16 \\
\hline $1940-1949$ & $1.03(5.93)$ & 11 & $1.03(6.74)$ & 12 \\
\hline (Missing Data) & Ger & & Kor, Neth, Twn & \\
\hline $1950-1959$ & $1.02(13.9)$ & 12 & $0.88(17.3)$ & 16 \\
\hline $1960-1969$ & $0.92(9.74)$ & 12 & $0.67(8.06)$ & 16 \\
\hline $1970-1979$ & $0.91(8.68)$ & 12 & $0.84(7.01)$ & 16 \\
\hline $1980-1989$ & $0.68(5.96)$ & 12 & $0.54(4.8)$ & 16 \\
\hline
\end{tabular}

* Taylor's data include Argentina, Australia, Canada, Denmark, France, Germany, Italy, Sweden, the UK and the U.S.

* Larger data include Taytor's data plus India, Korea, the Netherlands and Taiwan. 


\section{Maddison's \# of OBS Taylor's \# of OBS}

$\begin{array}{lcccc}1870-1879 & 0.51 & 9 & 0.6 & 8 \\ 1880-1889 & 0.42 & 11 & 0.38 & 10 \\ 1890-1899 & 0.017 & 11 & 0.58 & 11 \\ 1900-1909 & 0.584 & 13 & 0.72 & 12 \\ 1910-1919 & 0.734 & 14 & 0.72 & 12 \\ 1920-1929 & 0.528 & 14 & 0.48 & 12 \\ 1930-1939 & 0.517 & 14 & 0.9 & 12 \\ 1940-1949 & 0.733 & 10 & 1.02 & 12 \\ 1950-1959 & 0.9 & 15 & 1.01 & 12 \\ 1960-1969 & 0.896 & 15 & 0.92 & 12 \\ 1970-1979 & 0.906 & 15 & 0.92 & 12 \\ 1980-1989 & 0.54 & 15 & 0.71 & 12\end{array}$

* Maddison's data include Denmark, Italy, Norway, Sweden, the UK, the US, India, Korea, Australia, Canada, France, Germany, Japan, Taiwan and Holland..

* Taylor's data include Argentina, Australia, Canada, Denmark, France, Germany, Italy, Sweden, the UK and the U.S. 